\title{
Kepribadian Big Five terhadap Keputusan Pembelian Kosmetik Korea pada Remaja Fandom Korea
}

\author{
Feby Sri Setiawati ${ }^{1}$, Itto Nesyia Nasution ${ }^{2}$ \\ Fakultas Psikologi Universitas Abdurrab Pekanbaru \\ febyitusri@gmail.com ${ }^{1}$, itto.nesyia.nasutio@Univrab.ac.id
}

\begin{abstract}
Abstrak
Penelitian ini bertujuan untuk mengetahui hubungan antara big five dan keputusan untuk membeli kosmetik Korea pada remaja fandom Korea di Kota Pekanbaru. Populasi dalam penelitian ini adalah remaja fandom Korea di Kota Pekanbaru dengan jumlah sampel 110 orang. Teknik pengumpulan data dalam penelitian ini menggunakan dua skala psikologis, yaitu skala keputusan pembelian dan skala adaptasi big five inventory (BFI). Hasil koefisien korelasi menghasilkan $\mathrm{R}=0,991$ dengan tingkat signifikansi $\mathrm{p}=0,019(\mathrm{p}<0,05)$ yang berarti bahwa ada hubungan antara lima kepribadian besar dan keputusan untuk membeli kosmetik Korea pada remaja fandom Korea di kota Pekanbaru. Hasil penelitian ini diperoleh bahwa openness to experience dan agreeablesness memiliki hubungan yang signifikan dengan keputusan pembelian masing-masing 0,003 dan 0,024 yang didukung oleh sumbangan efektif sebesar $7,05 \%$ dan 4,23\%. Sedangkan extraversion, conscientiousness, dan neuroticism, tidak memiliki hubungan dengan keputusan pembelian.
\end{abstract}

Kata Kunci : Big five, keputusan pembelian, hallyu wave

\begin{abstract}
This study aims to determine the relationship between the big five inventory toward Korean cosmetics purchase decision-making in fandom teens in Pekanbaru City. The population in this study was Korean fandom teenagers in Pekanbaru City with a sample of 110 people. Data collection techniques in this study used two scales, the purchase decision scale and the big five inventory (BFI) The results of the correlation coefficient produce $\mathrm{R}=$ 0.991 with a significance level of $\mathrm{p}=0.019(\mathrm{p}<0.05)$ which means that there is a relationship between the five big personalities toward purchase decision-making of Korean cosmetics in Korean fandom teens of Pekanbaru. The results of this study found that openness to experience and agreeablesness had a significant relationship with purchasing decisions with value 0.003 and 0.024 , and contributions of $7.05 \%$ and $4.23 \%$. Whereas extraversion, conscientiousness, and neuroticism, was not significant toward purchasing decisions.
\end{abstract}

Keywords: Big five, purchase decision-making, hallyu wave

\section{PENDAHULUAN}

Budaya Korea menjadi salah satu brand yang berkembang dengan pesat yang menembus pasar Internasional. Demam budaya Korea ditingkat global yang dikenal sebagai "Hallyu" atau "Korean Wave" (Mutiara, 2018). Menurut Simbar (2016) Indonesia menjadi salah satu negara yang terkena dampak dari hadirnya budaya Korea Selatan. Mulai dari musik maupun serial drama (Achmada \& Sadewo, 2014). Di Pekanbaru, masuknya demam Korea di tandai dengan munculnya berbagai komunitas fandom, seperti EXO-Stand (fans EXO), Shawol (fans SHINee), fandom, E.L.F (fans Super Junior) dan lainnya(Rena, 2017).

Para fans sering kali menyisihkan uang jajan untuk membeli sebuah album original Idol dengan harga mahal, pernak-pernik seperti kaos, gelang, kalung, gantungan handphone, kosmetik, pakaian dan lainnya (Achmada \& Sadewo, 2014; Rena, 2017; Syah, 2018). Komunitas pencinta Korea pada umumnya beranggotakan remaja, bahkan member-member 
yang baru bergabung dalam komunitas masih berstatus sebagai siswa Sekolah Menengah Atas (SMA)(Achmada \& Sadewo, 2014; L. M. K. Sari, Joanna, \& Ayu Mei Lestari, 2013). Keanggotaan dengan umur yang sama atau di sebut peer group tidak hanya dapat membentuk kesamaan referensi namun mempengaruhi individu dalam melakukan pengambilan keputusan pembelian (Barkhi \& Wallace, 2007; I. A. Sari, Hamiyati, \& Rasha, 2019).

Santy (2018) mengungkapkan bahwa kepribadian memengaruhi perilaku pembelian seseorang, dimana kepribadian konsumen mengarah pada perilaku, sehingga individu cenderung memilih produk yang sesuai dengan kepribadiannya. Kepribadian konsumen akan memengaruhi persepsi dan pengambilan keputusan untuk membeli. Setiap individu memiliki tipe kepribadian tertentu.

Beberapa penelitian (Jariah, 2012; Onu J. C, Akhimien E, 2014; Santy, 2018; Shakaib Farid \& Ali, 2018; Udo-Imeh, 2015; Verplanken \& Herabadi, 2001) menunjukkan hasil yang bervariasi dalam hubungan kepribadian dengan keputusan pembelian. Udo-Imeh (2015) menyebutkan bahwa terdapat hubungan antara kepribadian dengan keputusan pembelian, meliputi openness to experience, extraversion, conscientiousness, agreeableness dan neuroticism, meskipun juga di sebutkan bahwa neuroticism memiliki kontribusi yang lebih rendah di banding kepribadian lainnya. Santy (2018) mengungkapkan bahwa sifat keterbukaan (openness to exsperience) mempunyai hubungan yang positif dengan pembelian terhadap produk yang diminati. Quintelier (2014) menambahkan bahwa keterbukaan individu terhadap pengalaman secara khusus dapat mengarahkan konsumen dalam berperilaku.

Individu yang memiliki kepribadian Neuroticism memiliki hubungan positif dengan pembelian implusif (Shakaib Farid \& Ali, 2018). Namun berbeda dengan penelitian Sofi dan Najar (2018) yang menyebutkan Neuroticism berhubungan negatif dengan pembelian impulsive. Sedang Verplanken dan Herabadi (2001) mengungkapkan bahwa individu yang memiliki kepribadian extraversion memiliki hubungan positif dengan pembelian.

Individu yang memiliki kepribadian conscientiousness yang tinggi dalam membeli suatu produk akan mendapatkan informasi sebanyak-banyaknya tentang produk tersebut, sebaliknya conscientiousness yang rendah dalam membeli suatu produk akan menyebabkan individu kurang mencari informasi tentang produk yang akan dibelinya (Ali \& Mohammad, 2014). individu dengan kepribadian conscientiousness memiliki hubungan negatif dengan pembelian impulsif (Shakaib Farid \& Ali, 2018; Verplanken \& Herabadi, 2001). Menurut Verplanken dan Herabadi (2001) orang-orang dengan kepribadian agreeableness memiliki kecenderungan melakukan pembelian secara tidak rasional dan didorong oleh adanya kepuasan setelah melakukan pembelian, namun dimensi ini tidak memiliki hubungan dengan pembelian impulsif. Perbedaan beberapa temuan penelitian di atas kemudian menjadi dasar penelitian ini, untuk melihat pendekatan big five pada trait-trait dalam diri individu yang selanjutnya akan dilihat "Hubungan Antara Kepribadian Big Five Personality dengan Keputusan Pembelian Kosmetik Korea Pada Remaja Fandom Korea.

\section{METODE}

Subjek penelitian ini berjumlah 110 orang remaja member K Pop di Pekanbaru, dengan teknik sampling kuota. subjek terdiri dari 6 orang laki-laki dan 104 perempuan dengan rata-rata usia 19,1. Alat ukur yang digunakan dalam penelitian ini menggunakan skala kepribadian (big five personality) diukur berdasarkan dimensi kepribadian (big five personality) menurut John (1990) yang kemudian diterjemahan ke versi bahasa Indonesia oleh Ramdhani (2012). Skala 
ini terdiri dari 44 aitem, dengan respon jawaban dari 1 (sangat tidak setuju ) sampai 5 (sangat setuju). Reliabilitas $\alpha$ untuk skala kepribadian big five personality dari kelima dimensi yaitu; extraversion 0.73 , agreeableness 0.76 , conscientiousness 0.78 , neuroticism 0.74 dan openness to exsperience 0.79, sedangkan dari hasil try out yang telah dilakukan didapatkan hasil reliabilitas dari kepribadian big five diantaranya extraversion 0.709 , agreeableness 0.705 , conscientiousness 0.707 , neuroticism 0.710 , dan openness to exsperience 0.823 .

Skala keputusan pembelian disusun berdasarkan komponen-komponen keputusan pembelian menurut (wasta, Irawan, dan Dharmesta (2008) yaitu : keputusan tentang jenis produk, keputusan tentang bentuk produk, keputusan tentang merek produk, keputusan tentang penjualan, keputusan tentang jumlah produk, keputusan tentang waktu pembelian, dan keputusan tentang cara pembayaran. Skala ini terdiri dari 25 aitem dengan menggunakan model likert dari 1 (sangat tidak setuju) sampai 5 (sangat setuju) pada aitem favorable dan bernilai kebalikan pada aitem unfavorable. Reliabilitas untuk skala keputusan pembelian sebesar 0,884 sebesar.

\section{HASIL}

Penelitian ini dilakukan di kota Pekanbaru. Berdasarkan data remaja fandom Korea berjumlah 110 orang. Diperoleh gambaran umum subjek penelitian seperti tertera pada tabel 1, sebagai berikut ini:

Tabel 1. Jenis kelamin

\begin{tabular}{ccc}
\hline Jenis Kelamin & Jumlah & Persentase (\%) \\
\hline Laki-laki & 6 orang & $5,5 \%$ \\
Perempuan & 104 orang & $94,5 \%$ \\
\hline Total & $\mathbf{1 1 0}$ orang & $\mathbf{1 0 0 \%}$ \\
\hline
\end{tabular}

Dari tabel 1 di atas diketahui subjek terbanyak dalam penelitian ini memiliki jenis kelamin laki-laki yang berjumlah 6 orang $(5,55 \%)$, sedangkan untuk subjek berjenis kelamin perempuan sebanyak 104 orang $(94,5 \%)$.

Tabel 2. Rentang Usia Subjek Penelitian

\begin{tabular}{rcc}
\hline Usia & Jumlah Subjek & Persentase \\
\hline 16-19 Tahun & 76 Orang & $69.09 \%$ \\
20-23 Tahun & 24 Orang & $21.82 \%$ \\
24-27 Tahun & 10 Orang & $9.09 \%$ \\
\hline & $\mathbf{1 1 0}$ & $\mathbf{1 0 0 \%}$ \\
\hline
\end{tabular}

Pada tabel 2 dapat dilihat rentang usia subjek pada penelitian ini adalah dari usia 14 tahun sampai dengan usia 27 tahun. Usia 16-19 tahun sebanyak 76 orang (69.09\%), usia 20-23 tahun sebanyak 24 orang (21.82\%) dan usia 24-27 sebanyak 10 orang (9.09\%). Hasil uji normalitas dari variabel kepribadian big five dengan keputusan pembelian pada remaja Korea di kota Pekanbaru diperoleh, nilai $p$ sebesar 0,053 ( $p>0,05$ ) dan 0,107, dengan demikian dapat disimpulkan bahwa sebaran data variabel kepribadian big five dengan keputusan pembelian pada remaja Korea di kota Pekanbaru memiliki sebaran data yang normal. Berdasarkan hasil pengujian linearitas pada variabel kepribadian big five dengan keputusan pembelian diketahui 
bahwa $F=2.840$. Dengan taraf signifikansi 0,000, karena $\mathrm{p}<0,05$ dengan begitu data penelitian ini dikatakan linear.

Untuk uji hipotesis peneliti menggunakan teknik koefisien korelasi regresi berganda yang mana mengukur 5 dimensi kepribadian big five personality. Hasil uji korelasi masing-masing dimensi dapat dilihat pada tabel berikut:

Tabel 3. Uji Hipotesa

\begin{tabular}{lcccc}
\hline \multicolumn{1}{c}{ Keputusan Pembelian } & P & Beta & t & Keterangan \\
\hline $\begin{array}{l}\text { kepribadian } \text { openness to } \\
\text { exsperience }\end{array}$ & 0,003 & 0,32 & $3,019 * *$ & Signifikan \\
\hline kepribadian neuroticism & 0,125 & 0,15 & $-1,546$ & Tidak Signifikan \\
\hline kepribadian ekstraversion & 0,198 & $-0,13$ & $-1,296$ & Tidak Signifikan \\
\hline kepribadian agreeablenes & 0,024 & $-0,21$ & $-2,287 * *$ & Signifikan \\
\hline kepribadian conscientiousnees & 0,815 & 0,23 & 0,235 & Tidak Signifikan \\
\hline
\end{tabular}

Ket : $\mathrm{P}<0,05$

Berdasarkan dari tabel 3. di ketahui bahwa, ada hubungan antara agreeblenes terhadap keputusan pembelian dangan signifikansi sebesar 0,024 dan 0,003 pada Openness to experience. Sementara pada trait kepribadian lain, meliputi neuroticism, extraversion dan conscientiousness tidak memiliki hubungan signifikan dengan keputusan pembelian.

\section{PEMBAHASAN}

Dari hasil analisis penelitian ini diketahui bahwa terdapat hubungan antara kepribadian openness to exsperience dengan keputusan pembelian. Hal ini sesuai dengan ciri-ciri yang di utarakan oleh Pervin, Cervone, dan John (2010)) dari kepribadian openness to exsperience yaitu memiliki keterbukaan wawasan, dimana remaja fandom Korea memiliki kepribadian openness to exsperience mudah menerima informasi baru, memiliki wawasan yang luas serta menyukai hal-hal yang baru untuk di pelajari, apa lagi jika informasi yang didapatkan adalah informasi terbaru dan menyangkut fandom yang disenangi. Penelitian ini didukung juga oleh Santy (2018) dalam penelitiannya menungkapkan bahwa sifat openness to exsperience mempunyai hubungan yang positif dengan pembelian terhadap produk yang diminati.

Narooi dan Karazee, (2015) dalam penelitiannya mengungkapkan bahwa kepribadian openness to exsperience memiliki hubungan antara karakter kepribadian dan pengambilan keputusan. Di tambah lagi dengan Asad Shahjehan, Qureshi, Zeb, dan Saifullah (2012) menyatakan bahwa kepribadian openness to exsperience memiliki hubungan yang signifikan terhadap pembelian implusif namun tidak berhubungan dengan pembelian kompulsif. Hal ini dapat terjadi pada remaja fandom yang melakukan pengambilan keputusan pembelian dengan berdasarkan pada kelompok referensi (keanggotaan sebagai member k-pop) (Ridaryanthi, 2014), tanpa mempertimbangkan manfaat atau kegunaan produk. Kepribadian openness juga menyebabkan individu mudah percaya dalam melalukan pembelian, tidak hanya pada pembelian offline tapi juga online (Gumelar \& Pandina, 2014; Rena, 2017). Hal ini semakin menegaskan bahwa individu dengan kepribadian openness lebih cepat mengambil keputusan dalam pembelian produk (Iskandar \& Zulkarnain, 2013) . 
Kepribadian neuroticism pada penelitian ini di dapatkan hasil bahwa tidak ada hubungan antara kepribadian neuroticism dengan keputusan pembelian produk kosmetik Korea pada remaja di kota Pekanbaru. Hal ini sejalan dengan yang di sampaikan oleh penelitian Quintelier (2014) bahwa emotional stability ataupun neuroticism tidak memiliki pengaruh signifikan terhadap perilaku konsumen. Pervin et al., (2010) menyatakan bahwa individu yang memiliki kepribadian neuroticism yang tinggi mencakup perasaan negatif, sehingga orang dengan dimensi ini cenderung mengalami kecemasan, rasa sedih, rasa rapuh, dan ketegangan saraf, merasa tidak aman, dan sensitif. Jika dikaitkan dengan fandom Korea orang dengan kepribadian neuroticism yang tinggi akan sulit bergaul dengan orang lain, selalu berprasangka buruk kepada orang lain. Hal ini juga ditegaskan oleh Gumelar dan Pandina (2014) bahwa orang dengan kepribadian neurotiscism kurang mudah mempercayai pihak lain untuk melakukan pembelian produk. Menurut Turkyilmaz, Erdem, dan Uslu (2015) juga berpendapat bahwa kepribadian neuroticism tidak memiliki hubungan terhadap pembelian impuls online. Jika dikaitkan dengan penelitian diatas remaja fandom tidak memiliki hubungan dengan keputusan pembelian, remaja fandom Korea tidak mengalami kecemasan jika akan melakukan transaksi pembelian karena sebelumnya remaja mendapatkan banyak referensi-referensi dari teman-teman sefandomnya.

Hasil penelitian ini kepribadian ekstraversion tidak memiliki hubungan yang signifikan dengan keputusan pembelian produk kosmetika Korea pada remaja di kota Pekanbaru. Esfahan dan Etemadi (2012) dalam penelitiannya menyatakan bahwa kepribadian ekstraversion tidak memiliki hubungan terhadap pengambilan keputusan. Menurut Pervin, Cernove \& John (2010) kepribadian ekstraversion sendiri memiliki ciri-ciri percaya diri, dominan, aktif, dan menunjukkan emosi yang positif, selain itu juga dikaitkan dengan kecenderungan untuk bersifat

Pada penelitian ini kepribadian agreeablenes memiliki hubungan yang signifikan pada keputusan pembelian. Hal ini sesuai dengan kepribadian agreeablenes dimana orang dengan kepribadian ini memiliki percaya, jujur, patuh pada aturan, rendah hati, dan mudah diubah pendiriannya, sehingga orang yang nilainya tinggi pada dimensi akan cenderung ramah, kooperatif, mudah dipercaya, dan hangat. Bagi anggota fandom Korea yang memiliki kepribadian ini biasanya tidak teguh pendiriannya dan suka mengikut-ikut teman sebayanya, biasanya disukai banyak teman yang ada dilingkungannya, dapat bekerja sama dalam kelompok. Narooi dan Karazee (2015) dari hasil penelitian yang mereka lakukan bahwa kepribadian agreeablenes memiliki hubungan pengambilan keputusan. Shahjehan dan Qureshi, (2019) menyatakan bahwa kepribadian agreeablenes memiliki hubungan yang signifikan terhadap pembelian kompulsif. Remaja merupakan individu yang labil, pada umumnya remaja yang ikut masuk ke dalam sebuah fandom sebelumnya pasti sudah memiliki barang-barang yang berhubungan dengan famdom yang disukai. Tidak lain halnya seperti poster, remaja yang menyukai fandom memiliki banyak koleksi poster dirumahnya, walaupun remaja sudah memilik poster tetapi jika muncul poster baru, remaja tanpa berfikir panjang akan langsung membelinya walaupun dengan harga mahal. Udo-Imeh (2015)juga berpendapat bahwa kepribadian agreeableness memiliki pengaruh paling kuat terhadap pembelian.

Kepribadian conscientiousnees pada penelitian ini yaitu hubungan antara kepribadian conscientiousnees dengan keputusan pembelian produk kosmetik Korea pada remaja di kota Pekanbaru. Farid dan Ali (2018) dalam penelitiannya juga mengatakan bahwa kepribadian conscientiousnees tidak memberikan hasil yang signifikan terhadap pembelian implusif. Turkyilmaz, Erdem dan Uslu (2014) juga berpendapat bahwa kepribadian conscientiousness tidak memiliki hubungan terhadap pembelian impuls online. Hal ini sesuai dengan pendapat Pervin, Cernove dan John (2010) menyatakan bahwa individu yang memiliki kepribadian 
conscientiousnees yang rendah memiliki ciri-ciri keinginan lemah, suka bersenang-senang. Remaja dengan kepribadian ini biasanya menyukai barang-barang yang berhubungan dengan fandom tetapi untuk memilikinya individu merasa berat, cukup dengan melihat milik teman yang telah memberi dan mengetahui barangnya saja individu sudah cukup. Berbeda dengan penelitian yang dilakukan oleh Otero-López dan Villardefrancos (2013)dalam penelitiannya menyatakan bahwa kepribadian conscientiousnees memiliki hubungan negatif antara pembelian kompulsif.

Secara menyeluruh hasil dari penelitian ini didapat bahwa kepribadian Openness to exsperience dan agreeableness memiliki hubungan antara keputusan pembelian produk kosmetik Korea pada remaja di kota Pekanbaru. Semakin tinggi skor dimensi kepribadian Openness to exsperience dan skor kepribadian agreeableness maka semakin tinggi pula skor keputusan pembelian. Sedangkan kepribadian conscientiousnees, neuroticism, dan ekstraversion pada penelitian ini didapatkan hasil bahw tidak memiliki hubungan terhadap keputusan pembelian. Beberapa hasil temuan dalam penelitian kepribadian big five masih ada inkonsistensi dengan temuan penelitian ini, sehingga bisa dijadikan masukkan untuk penelitian selanjutnya.

\section{SIMPULAN}

Berdasarkan hasil penelitian dan pembahasan maka dapat dilihat bahwa variabel komponen kepribadian big five personality pada remaja fandom Korea di kota Pekanbaru. Di dapatkan hasil bahwa ada hubungan yang signifikan antara kepribadian openness to experience dan agreeableness dengan keputusan pembelian kosmetik Korea pada remaja fandom Korea di kota Pekanbaru. Penelitian ini dapat dikaitkan penelitian berikutnya atau variabel lain, penelitian big five personality masih inkonsistensi sehingga perlu dilakukan penelitian lagi dengan mempertimbangkan mediator.

\section{DAFTAR PUSTAKA}

Achmada, L., \& Sadewo, F. S. (2014). Pola Perilaku Konsumtif Pecinta Korea di Korea Lovers Surabaya Community. Paradigma, 02, 7.

Ali, M., \& Mohammad, A. (2014). Psikologi Remaja : Perkembangan Peserta Didik. Jakarta: Bumi Aksara.

Asad Shahjehan, Qureshi, J. A., Zeb, F., \& Saifullah, K. (2012). The effect of personality on impulsive and compulsive buying behaviors. African Journal of Business Management, 6(6). https://doi.org/10.5897/ajbm11.2275

Barkhi, R., \& Wallace, L. (2007). The impact of personality type on purchasing decisions in virtual stores. Information Technology and Management, 8(4), 313-330. https://doi.org/10.1007/s10799-007-0021-y

Gumelar, G., \& Pandina, I. (2014). Trait kepribadian dan kepercayaan konsumen untuk berbelanja pada Toko Online. Perspektif Ilmu Pendidikan, 28(1), 75-81.

Iskandar, L. M., \& Zulkarnain. (2013). Penyesalan Pasca Pembelian Ditinjau dari Big Five Personality. Jurnal Psikologi, 40(1), 81-91. https://doi.org/10.22146/jpsi.7068

Jariah, A. (2012). Analisis faktor-faktor pribadi Yang Mempengaruhi keputusan pembelian 
sepeda motor. Jurnal WIGA, 2(2), 1-18.

Mutiara, I., \& Syahputra. (2018). Pengaruh pengetahuan produk dan produk halal terhadap keputusan pembelian pada produk kecantikan Korea. Jurnal Indonesia Membangun, $17(2), 153-154$.

Narooi, Z. S., \& Karazee, F. (2015). Investigating the Relationship among Personality Traits, Decision-making Styles, and Attitude to Life (Zahedan Branch of Islamic Azad University as Case Study in Iran). Mediterranean Journal of Social Sciences, 6(6), 311-317. https://doi.org/10.5901/mjss.2015.v6n6s6p311

Onu J. C, Akhimien E, O. M. G. (2014). Assessing the Relationship between Personality Factors and Consumer Buying Behavior in South Eastern Nigeria. International Journal of Business and Social Science, 5(11), 231-242.

Otero-López, J. M., \& Villardefrancos, E. (2013). Materialism and addictive buying in women: The mediating role of anxiety and depression. Psychological Reports, 113(1), 1342-1358. https://doi.org/10.2466/18.02.PR0.113x11z9

Pervin, L. A., Cervone, D., \& Oliver P John. (2010). Psikologi Kepribadian, Teori dan Penelitian Edisi kesembilan. Jakarta: Kencana.

Quintelier, E. (2014). The influence of the big 5 personality traits on young people's political consumer behavior. Young Consumers, 15(4), 342-352. https://doi.org/10.1108/YC-092013-00395

Rena, E. (2017). Komunitas K-POPERS Pekanbaru, Studi tentang pembentukan kelompok sosial. Jom FISIP, 4(2), 1-15.

Ridaryanthi, M. (2014). Bentuk Budaya Populer dan Konstruksi perilaku Konsumen ... Pop Culture, 13(01),

87-104. https://doi.org/https://media.neliti.com/media/publications/142786-ID-bentuk-budayapopuler-dan-konstruksi-per.pdf

Santy, R. D. (2018). Pembelian implusif ditinjau dari faktor kepribadian konsumen dengan menggunakan trait the big five personality. In Proceeding from JBPTUNIKOMPP. Bandung: JBPTUNIKOMPP. https://doi.org/10.1017/CBO9781107415324.004

Sari, I. A., Hamiyati, \& Rasha. (2019). Pengaruh Fungsi Peer Group Terhadap Pengambilan Keputusan Pembelian ( Pencarian Informasi ) Produk Kosmetik Pada Remaja Putri. Jurnal Kesejahteraan Keluarga Dan Pendidikan, 06(01), 1-8. https://doi.org/doi.org/10.21009/JKKP.061.01

Sari, L. M. K., Joanna, A. D., \& Ayu Mei Lestari. (2013). Analisis Pengaruh Persepsi Remaja Depok Terhadap Demam Korea. Proceeding PESAT (Psikologi, Ekonomi, Sastra, Arsitektur \& Teknik Sipil), 5(Oktober), 8-9.

Shahjehan, A., \& Qureshi, J. A. (2019). Personality and impulsive buying behaviors. A necessary condition analysis. Economic Research-Ekonomska Istraživanja, 32(1), 10601072. https://doi.org/10.1080/1331677x.2019.1585268

Shakaib Farid, D., \& Ali, M. (2018). Effects of Personality on Impulsive Buying Behavior: Evidence from a Developing Country. Marketing and Branding Research, 5(1), 31-43. 
https://doi.org/10.33844/mbr.2018.60197

Simbar, F. K. (2016). Fenomena Konsumsi Budaya Korea Pada Anak Muda Di Kota Manado. Jurnal Holistik, (18), 1-20.

Sofi, S. A., \& Najar, S. A. (2018). Impact of personality influencers on psychological paradigms: An empirical-discourse of big five framework and impulsive buying behaviour. European Research on Management and Business Economics, 24(2), 71-81. https://doi.org/10.1016/j.iedeen.2017.12.002

Swasta, B., Irawan, \& Dharmesta. (2008). Manajemen Pemasaran Modern. Liberty: Yogjakarta.

Syah, Y. I. (2018). Representasi budaya kaum muda perempuan sebagai penggemar Korean Pop. KINESIK, 5(1), 37-39.

Turkyilmaz, C. A., Erdem, S., \& Uslu, A. (2015). The Effects of Personality Traits and Website Quality on Online Impulse Buying. Procedia - Social and Behavioral Sciences, 175(August), 98-105. https://doi.org/10.1016/j.sbspro.2015.01.1179

Udo-Imeh, P. T. (2015). Influence of Personality on the Buying Behaviour of Undergraduate Students in Universities in Cross River State, Nigeria. International Journal of Marketing Studies, 7(4), 64-77. https://doi.org/10.5539/ijms.v7n4p64

Verplanken, B., \& Herabadi, A. (2001). Individual differences in impulse buying tendency: feeling and no thinking. European Journal of Personality, 15(S1), S71-S83. https://doi.org/10.1002/per.423 